\title{
POPULATION DYNAMICS AND FISHERY MANAGEMENT OF CIRRHINUS MRIGALA (HAMILTON, 1822) IN PAKISTAN
}

\author{
MoHSIN, M. ${ }^{1}-$ YIN, H. B. ${ }^{2 *}-$ ZHANG, S. J. ${ }^{2}-$ ZHANG, H. ${ }^{3}$ \\ ${ }^{I}$ College of International Finance and Trade, Zhejiang YueXiu University of Foreign \\ Languages, Shaoxing 312000, China \\ ${ }^{2}$ School of Finance and Trade, Wenzhou Business College, Wenzhou 325035, China \\ ${ }^{3}$ Shandong Foreign Trade Vocational College, Qingdao 266100, China \\ (phone: +86-187-6423-7235; fax: +86-187-6423-7235) \\ *Corresponding author \\ e-mail:20190251@wzbc.edu.cn; phone: +86-187-6423-7235; fax:+86-187-6423-7235
}

(Received $13^{\text {th }}$ Jan 2021; accepted $9^{\text {th }}$ Apr 2021)

\begin{abstract}
The study of environmental resources usually gets meagre attention particularly in developing countries. This is the first-attempt to study population dynamics and fishery management parameters of a very important aquatic environmental resource Cirrhinus mrigala (Mrigal carp) in Pakistan. For this, six monthly surveys, January to June 2020, collected 720 samples numbers (n), ranging (R) in size from 14 to 37 centimeters $(\mathrm{cm})(22 \pm 5.445)$ and weighing from 30 to 527 grams $(\mathrm{g})(148 \pm 110.673)$. Collected data was statistically analysed by FAO-ICLARM Stock Assessment Tools II (FiSAT-II). Length-weight relationship (LWR) for Mrigal carp was measured as $\mathrm{W}=0.014 \mathrm{~L}^{2.936}$ having goodness of fit $\left(\mathrm{R}^{2}\right)$ value of 0.987 . Computed values of asymptotic length $\left(\mathrm{L}_{\infty}\right)$ and growth coefficient $(\mathrm{K})$ were $38.85 \mathrm{~cm}$ and 0.180 years $^{-1}$. Other fishery parameters, viz., theoretical age at which length is zero $\left(t_{0}\right)$, growth performance index (GPI), total mortality (Z), natural mortality (M) and fishing mortality $(\mathrm{F})$ were estimated at $-0.056, \Phi^{\prime}=2.434$ year, $\Phi=1.130$ year, 1.170 years $^{-1}, 0.493$ years $^{-1}$ and 0.677 years $^{-1}$, correspondingly. Moreover, target reference point (TRP) for maximum sustainable yield (MSY) was calculated as $92160 \mathrm{~g}$. Thus, considering obtained results, it can be concluded that Mrigal carp fishery is degrading and biologically overfished at Chashma Barrage. Therefore, it is strongly recommended that catch should be reduced according to the TRP and conservation management policies should be implemented immediately.
\end{abstract}

Keywords: fishery administration, growth, mortality, FiSAT-II, Chashma Barrage

\section{Introduction}

The most endangered and affected species in the world are freshwater fishes. This decline of freshwater biodiversity is caused by habitat fragmentation and degradation, flow alteration, overharvest, pollution, and invasive species (Abell et al., 2007). Pakistan has the largest canal system (FAO, 2003; Sheikh et al., 2017) of rivers and freshwater the quality of which is very important for an animal that is decreasing in numbers day by day. Freshwater fish occur almost everywhere there is fresh water in rivers, streams, lakes, springs, swamps, and bogs and every continent except Antarctica. Each continent, and often each river basin, has a distinct fish fauna that is primarily due to the physical barriers that limit freshwater fish dispersal. As a general rule, diversity is lower in temperate regions and higher in tropical areas (Abell et al., 2007). Pakistan is blessed with significant natural water resources of rivers, lakes streams, estuaries, man-made reservoirs, dams, wetlands of approximately 3102408 hectares which are rich sources of floral diversity (FAO, 2003). It is endowed with a great deal of future fishery capital; this area has a variety of large basins for the development and spawning of much commercial fish. According to various reports, the total number of fresh-water fish species in Pakistan 
ranges from at least 160 species to a maximum of 193 (Mirza, 1975; Rafique, 2007; Khan et al., 2008; Rafique and Khan, 2012; Iqbal et al., 2013). Thus, these numbers indicate the emergence of exotic species in Pakistani freshwater. Among other factors, exotic species are a major cause of the depletion of fish species in various natural reservoirs. Chashma Lake District Mianwali is one of the selected locations in Punjab Pakistan, where the diversity indicates the presence of 39 fish species (Mirza and Bakar, 1993) while only 20 species were reported in 2008 (Khan et al., 2008). These species are classified by Actinopterygii class, Teleostei subclass, three cohorts, six superorder, thirty families, eighty-six genera, and thirteen genera respectively (Rafique, 2007). Pakistani freshwater consists of thirty-one commercially and economically important species out them (Rafique and Khan, 2012).

Cyprinidae is representative of about 376 genera and 3160 species of freshwater fish in the world (Pethiyagoda et al., 2012). They exist in the world's freshwater, brackish water, and seawater, but are mainly freshwater species. Carps belonging to warm-water fishes are the most important part of Ichthyofauna in the Indus Plain of Pakistan's freshwater rivers, and they are extensively developed and widely cultured in Pakistan (Rafique and Khan, 2012). This important carp family of freshwater fish originated in Southeast Asia and spread to Asia, Europe, North America, and Africa (excluding Madagascar) to other regions of the world (Mirza, 1975). Carps are considered to be the main source of protein in Pakistani waters, including Morakhi ( $C$. mrigala), Thaila (C. catla) and Rohu (L. rohita), and preferably these species on high economic values are cultured (Rafiq and Khan, 2012; Iqbal et al., 2013). In Pakistan, this family is distributed in 4 subfamilies of 26 genera represented by 65 species, and Barbinae is the largest subfamily of Cyprinidae represented by 43 species belonging to 13 genera in Pakistan (Mirza, 1975). Pakistan's freshwater fauna is dominated by the Cyprinidae family, and the genus Cirrhinus belongs to the two species $C$. mrigala and $C$. reba in the hills adjacent to the Indus Plain (Mirza, 1975; Rafique, 2007; Khan et al., 2008, Iqbal et al., 2013).

Scientifically this freshwater, demersal, and tropical fish species is known as C. mrigala, globally Mrigal carp (Nisha and Jain, 2018; FAO, 2020), commonly Morakha in Punjabi (Jhingran and Khan, 1979) and locally Mori (Iqbal et al., 2013). Greatly, this fish species of inland native water of commercial and economic importance is widely distributed in Pakistan (Mirza, 1975; Jhingran and Khan, 1979; Rafique and Khan, 2012; Iqbal et al., 2013), India, Bangladesh (Jhingran and Khan, 1979; Menon, 1999) Nepal (Menon, 1999) and Myanmar (Burma) (Phung, 1988) (endemic, indigenous, and introduced for cultural purposes). It is a potamodromous and benthic freshwater fish (Nisha and Jain, 2018) that normally travels from river to lake in freshwater and vice versa for spawning and nursery in natural water bodies as well as in lentic and lotic pumped environments, and almost shows better growth in natural open waters in rivers, lakes, and streams (Jhingran and Khan, 1979; Iqbal and Kausar, 2009). In feeding habits, it is a kind of illiophage and stenophagous, frequent bottom dwellers, omnivorous type, eurythermal tolerating temperatures of at least 14 degree centigrade $\left({ }^{\circ} \mathrm{C}\right)$ and surviving in open natural water bodies for 12 years (Jhingran and Khan, 1979). It is heterosexual (Jhingran and Khan, 1979) and reaches its first maturity at about 2 years of age. The spawning season in Pakistan occurs in July and shows high yields and fecundity for Mrigal carp, where monsoon rains also start in Lahore every July (Punjab-Pakistan) (Iqbal and Kausar, 2009) from the depths 0.5 to $1 \mathrm{~m}$ (Jhingran and Khan, 1979). It is a high-yield fish, spawning 100000-150000 eggs/kilogram (kg) body weight, usually breeding at $24-31{ }^{\circ} \mathrm{C}$. It is freshly sold at the price of 1.5 United States Dollar (USD \$) per kg in the 
national and domestic market of Pakistan, and it has important economic significance mainly used and consumed for food (personal observation, 2020). The carp is a major aquatic food item, where the major carp is Pakistan's trade fish. Comparatively, the global fast expansion growth was observed up to 1996, and the overall output of Mrigal carp remained constant until 2003. However, a comparatively decreasing pattern of growth was observed from 1958 to 1994 and reaches the maximum length and weight of 0.990 meters (m) and $12700 \mathrm{~g}$ (Menon, 1999; Froese and Pauly, 2019).

The fish population or stock is a biological entity and populations are made up of individuals of species within a designated region, whose boundaries apply to the geographical boundaries of the appropriate population (Abell et al., 2007). The distribution of the population may be restricted by natural barriers, and may also be restricted by certain environments that are conducive to its survival in a particular area. Awareness of population dynamics is an important and fundamental feature of fisheries biology in determining the condition and management of the deposits stock of fish (Hilborn and Walters, 1992; Hoggarth et al., 2006; Al-Barwani et al., 2007; Tah et al., 2010). The stocks of fishes are the concerns developed by natural management mechanisms and sustainable stocks and affected when ignorant and oblivious exploitations are used may result in overfishing and mortality of the stock (Hilborn and Walters, 1992; Hoggarth et al., 2006). The measurement of the length-frequency distribution data (LFD) is fundamental to many aspects of fisheries science (Al-Barwani et al., 2007; Tah et al., 2010). The length depends on the desired purpose of the sample specimen and the shape of the length-frequency is more important than the sum of a simple statistic such as meaning or variation that is more important than the method of evaluation (Gerritsen and McGrath, 2007). To determine the condition of fish population size in nature, the length of fish distribution is important (Jisr et al., 2018). This is the first step in evaluating the accuracy of catches made of different gear types in the same water. One of the most commonly used methods of statistical fisheries data analysis is LWR (Ricker, 1975). The relationship between body length and body weight is important in fisheries studies in estimating weight only when length data is available (Sparre and Venema, 1992). This is very important in fishery biology studies and fish population assessments, the biomass of existing stock or yield can be estimated and LWR can be used to track seasonal changes in fish growth (LeCren, 1951; Ricker, 1975).

In the past few decades, population explosions have posed a huge threat to fish populations. Due to the destruction of habitat by natural and human factors, the diversity of fish has significantly reduced and declined to a large extent (Abell et al., 2007). On the population dynamics and stock assessment of Mrigal carp from the world some studies are accounted in the Kaptai Reservoir, Bangladesh by Ahmed et al. (2004), Rani Palaniswamy et al. (2011) India, in the Thirumoorthy Reservoir and Mayank et al. (2017) India, in the Ganga River. Even with the commercial and economic importance of Mrigal carp, no research has been done by Pakistan on population dynamics. Not just a few attempts at dealing with recent studies on fauna with fauna from different sides on this species by Mirza (1975); Khan et al. (2008); Rafique (2007); Rafique and Khan (2012) and Iqbal et al. (2013). Various population dynamics studies have been conducted in the seawater of Pakistan, but there are few studies on freshwater species. Freshwater fish can be used to investigate and test several factors that affect the structure of fish communities. Fish type is also an important indicator of environmental health and abundance of fish that reflects the health of the body of water. Chashma Barrage along the Indus River lacks knowledge of the management of this freshwater fish population, lack of ecological 
understanding and awareness of the protection of Mrigal carp, highlighting the importance of identifying freshwater fish populations and the need to manage this national cooperation on commercial and economic freshwater fish stocks. The purpose of this study is to take the first step to identify the various parameters of population dynamics of Mrigal carp, allowing stakeholders and policymakers to properly manage and protect this economically important fishery and also will help in determining what course of action to be taken to outline possible mechanisms for promoting and facilitating such behavior in this area. This study also evaluates the concentrates the parameters of growth and mortality of Mrigal carp in the Chashma Barrage on the River Indus. Ultimately, based on approximate biological reference points (BRPs), it is important to provide local fishery managers with knowledge on the sustainable exploitation of the natural stock basis.

\section{Materials and methods}

\section{Data collection}

\section{Survey area sampling}

From January 2020 to June 2020, six surveys were conducted on the Chashma Barrage of the Indus River in Pakistan each month. Samples of Mrigal carp fish specimens are collected from artisanal-fishermen primarily using nylon nets (gillnets, purse seine, cast

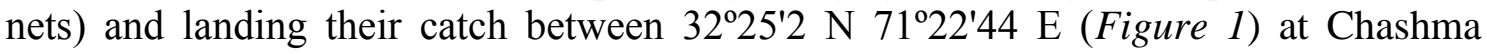
Barrage on the left bank of the Indus River in Mianwali district. The fishing effort was done by using gill nets, purse seine nets (Katra net), and cast nets with varying lengths, height, and meshes sizes knot to knot to capture as many fish species as possible (Khan et al., 2008). The Chashma Barrage was built in 1971 near the village of Chashma on the Indus River. The reservoir is 3536 feet long, 3120 feet by direct channel, and a total of drainage 1.1 million cubic feet at Chashma, and the river valley is 6.5 miles wide. The highest flood level at Chashma Barrage is 37 feet and it has 52 bays, each 60 feet long (Khan et al., 2008). The height of the left and right banks is 4302 feet. The fish industry is the main economic source for the populace of the area and home to a wide variety of fish that live in large habitats (Mirza and Bakar, 1993; Khan et al., 2008).

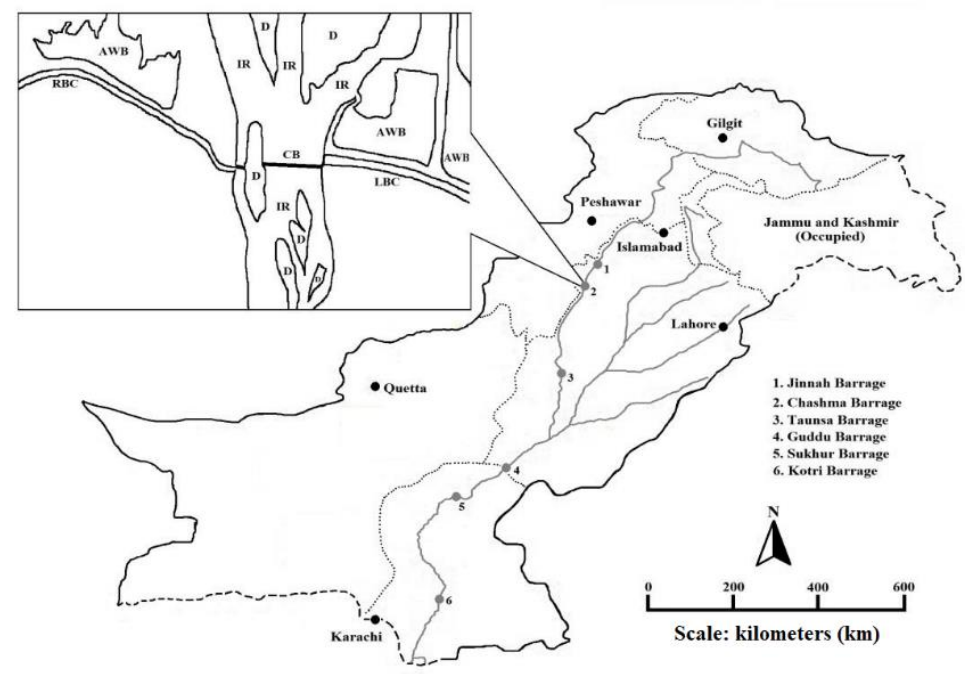

Figure 1. Collection localities of Mrigal carp at Chashma Barrage on Indus River, Pakistan 
For data procurement, $n=720$ of Mrigal carp were analyzed: 103, 137, 120, 130, 122 , and 108 in January, February, March, April, May, and June 2020, respectively. The paired data of the length and weight samples are prepared for statistical analysis. The fork length (FL) was measured in $\mathrm{cm}$ and the weight was recorded in $\mathrm{g}$. Each sample was measured from the tip of the central caudal-fin ray to the nose and edge for the measurement FL. Lake Chashma is home to at least 49 genera, 16 families, and 9 orders of native fish. Downstream of Chashma Barrage, the Indus River is very slow and there is little change in the fauna of the fish. However, some species of the Indus Plain are closely and evenly distributed. The average total length (TL) and total weight (TW) of all individual $(n=720)$ was $22 \mathrm{~cm}$, standard deviation ( $\mathrm{SD} \pm 5.445 \mathrm{~cm})$, and $148 \mathrm{~g}(\mathrm{SD} \pm 110.673 \mathrm{~g})$.

\section{Data analysis}

Monthly LFD or statistics of Mrigal carp have been analyzed using FiSAT-II software (Gayanilo et al., 2005) and each month the frequency distribution of $5 \mathrm{~cm}$ intervals size was established from the series data (Table 1). In this study, eight different scientific models: LWR, $\mathrm{L}_{\infty}$ and $\mathrm{K}, \mathrm{Z}, \mathrm{M}, \mathrm{F}$, virtual population analysis (VPA), relative yield analysis (Y/R), BRPs, $\Phi^{\prime}$, and MSY are evaluated, and detailed information about the description of these models is given in the coming sections.

Table 1. Number of individuals examined in various months and size classes in the population of Mrigal carp (Chashma Barrage) in 2020

\begin{tabular}{c|c|c|c|c|c|c|c|c}
\hline Size classes & January & February & March & April & May & June & $\begin{array}{c}\text { Total sample } \\
\text { numbers }\end{array}$ & Percentage \\
\hline $11-15$ & 4 & 0 & 0 & 0 & 0 & 0 & 4 & 0.556 \\
$16-20$ & 79 & 84 & 33 & 6 & 7 & 12 & 221 & 30.694 \\
$21-25$ & 20 & 53 & 87 & 106 & 24 & 26 & 316 & 43.889 \\
$26-30$ & 0 & 0 & 0 & 18 & 57 & 1 & 76 & 10.556 \\
$31-35$ & 0 & 0 & 0 & 0 & 31 & 56 & 87 & 12.083 \\
$36-40$ & 0 & 0 & 0 & 0 & 3 & 13 & 16 & 2.222 \\
\hline$\sum$ & 103 & 137 & 120 & 130 & 122 & 108 & 720 & 100 \\
\hline
\end{tabular}

\section{Parameters of $L W R$}

LWR of Mrigal carp is estimated by the power function of the following equation (Eq. 1) (Le Cren, 1951).

$$
\mathrm{W}=\mathrm{aL}^{\mathrm{b}}
$$

In this mathematical equation, weight (W) represents the TW of the fish in $\mathrm{g}$, the intercepts or condition factor represents (a), (b) signifies the slope or exponent (allometric growth parameter), and (L) denotes the TL in $\mathrm{cm}$.

\section{Parameters of growth}

The pattern of growth of Mrigal carp was determined by electronic length-frequency analysis (ELEFAN-I) in this study. This method generates an estimate of the growth parameters directly using the size distribution. The initial estimate of $\mathrm{L}_{\infty}$ and $\mathrm{K}$ was calculated using ELEFAN-I and Von Bertalanffy Growth function (VBGF) model (Eq. 2) (Haddon, 2011).

$$
\mathrm{L}_{\mathrm{t}}=\mathrm{L}_{\infty}\left[1-\exp \left\{-\mathrm{K}\left(\mathrm{t}-\mathrm{t}_{0}\right)\right\}\right]
$$


Two new factors indicated in the above equality are predicted length at age $t\left(\mathrm{~L}_{\mathrm{t}}\right)$ and $\mathrm{t}_{0}$. Using empirical equation (Eq. 3) the value of $\mathrm{t}_{0}$ is estimated (Pauly, 1983).

$$
\log _{10}\left(-\mathrm{t}_{0}\right)=0.3922-0.275 \log _{10} \mathrm{~L}_{\infty}-1.083 \log _{10} \mathrm{~K}
$$

\section{Parameters of estimation of mortalities}

To estimate the $\mathrm{Z}$ the equation in length converted catch curve (LCCC) method is used (Eq. 4).

$$
\ln \left(N_{i} / \Delta t_{i}\right)=a+b \cdot t_{i}
$$

The number of fishes in length $N_{i}$ classes $i$ is category, $\Delta t_{i}$ which is the time required to pass the development to length classes i category, $t_{i}$ is the age or relative age calculated $\mathrm{t}_{0}=0$ corresponds to the intermediate length of the classes $\mathrm{i}$ category, whereas the $\mathrm{b}$ gives the estimated Z. From the equation (Eq. 5) M is estimated (Pauly, 1980).

$$
\log _{10} \mathrm{M}=0.0066-0.279 \log _{10} \mathrm{~L}_{\infty}+0.654 \log _{10} \mathrm{~K}+0.4634 \log _{10} \mathrm{~T}
$$

The population of Mrigal carp in the Chashma Barrage occurred at the $23^{\circ} \mathrm{C}$ annual average surface temperature of the water (T). From the equation $(E q .6) \mathrm{F}$ is estimated (Sparre and Venema, 1992).

$$
\mathrm{F}=\mathrm{Z}-\mathrm{M}
$$

Whereas by the equation (Eq. 7) the exploitation rate (E) is calculated (Gulland, 1971a).

$$
\mathrm{E}=\mathrm{F} / \mathrm{Z}=\mathrm{F} /(\mathrm{F}+\mathrm{M})
$$

\section{Length structured virtual population analysis (LSVPA)}

It is executed using the input value of LWR parameters, growth parameters, mortality parameters to estimate F by length class of Mrigal carp by the method of Sparre and Venema (1992). The $t_{0}$ value was considered zero.

\section{Analysis of $Y / R$}

Beaverton and Holt's (1957) model was employed in the FiSAT-II program (Gayanilo et al., 2005) to obtain the correlation of $\mathrm{Y} / \mathrm{R}$ with the formula for estimating residual values of Mrigal carp (Eq. 8).

$$
Y_{w} / R=F W_{\infty} e^{-M\left(t_{c}-t_{r}\right)} \sum_{n=0}^{3} \frac{Q_{n} e^{-n K\left(t_{c}-t_{0}\right)}}{F+M+n K}\left(1-e^{-(F+M+n K)\left(t_{\lambda}-t_{c}\right)}\right)
$$

This mathematical expression $Y_{W} / R$ was yield per recruit, $t_{c}$ was the average age of the first capture, $t_{r}$ was the age of recruitment, $t_{\lambda}$ was the asymptotical age. The value of $\mathrm{Q}_{\mathrm{n}}$ was constant and equal to $1,-3,3$, and -1 when $\mathrm{n}$ was correspondingly $0,1,2$, and 3 (Pitcher and Hart, 1982). 
BRPs

The Gulland (1969) method (Eq. 9) was used to calculate BRPs and the hypothesis of this method is used as BRP for Mrigal carp in the Chashma Barrage, i.e., optimum fishing mortality $\left(\mathrm{F}_{\mathrm{opt}}\right)$.

$$
\mathrm{F}_{\mathrm{opt}}=\mathrm{M}
$$

$G P I$

The estimated growth parameters of $\mathrm{L}_{\infty}$ and $\mathrm{K}$ are used to calculate the performance index by phi prime $\left(\Phi^{\prime}\right)$. From the following equations $(E q .10)$, the reliability of the growth parameter is obtained (Pauly and Munro, 1984).

$$
\Phi^{\prime}=\log _{10} \mathrm{~K}+2 \log _{10} \mathrm{~L}_{\infty} \text { and } \Phi=\log _{10} \mathrm{~K}+2 / 3 \log \mathrm{W}_{\infty}
$$

$M S Y$

MSY, average standing stock size, and total annual stock size of Mrigal carp was estimated. From the equation $(E q .11)$ the correlation rate of the exploitation rate is estimated by the method Beverton and Holt (1957) and Ricker (1975) to find exploitation ratio $(\mathrm{U})$.

$$
\mathrm{U}=\mathrm{F} / \mathrm{Z} *\left(1-\mathrm{e}^{-\mathrm{z}}\right)
$$

The landing data of Mrigal carp was collected from the Chashma Barrage of different landing sites to estimate the annual yield (Y) of the year 2020. Then, the total annual stock $\mathrm{P}=\mathrm{Y} / \mathrm{U}$ and the average standing stock biomass $\mathrm{B}=\mathrm{Y} / \mathrm{F}$ from the values of $\mathrm{U}, \mathrm{F}$, and $\mathrm{Y}$ is used and determined. From $\mathrm{Y} / \mathrm{F}$ the biomass ratio is estimated where $\mathrm{Y}$ and $\mathrm{B}$ of the harvested catch is in $\mathrm{g}$, respectively. Y of the Mrigal carp is $106653 \mathrm{~g}$ during the year 2020. The MSY was then calculated by the method (Eq. 12) of Gulland (1979).

$$
\mathrm{MSY}=\mathrm{Z}_{\mathrm{t}} * 0.5 * \mathrm{~B}_{\mathrm{t}}
$$

Whereas, $Z_{t}$ was the total annual mortality and $B_{t}$ was the stock size standing in the year.

\section{Results}

\section{LWR parameters}

Y of Mrigal carp was $106653 \mathrm{~g}(\mathrm{n}=720)$ from Chashma Barrage on the Indus River during January to June, 2020. The average TL and TW of the annual stock ranged between 14 to $37 \mathrm{~cm}$ at an average of $22 \pm 5.445 \mathrm{~cm}$ (Coefficient of variation, i.e., $\mathrm{CV}=0.242$ ) and 30 to $527 \mathrm{~g}$ with an average of $148 \pm 110.673 \mathrm{~g}(\mathrm{CV}=0.747)$, accordingly. LWR of Mrigal carp was described by the power equation as $\mathrm{W}=0.014 \mathrm{~L}^{2.936}$ and $\mathrm{R}^{2}=0.987$ for the total annual catch in Figure 2. Dominant length and weigh range were 19 to $23 \mathrm{~cm} 55$ to $100 \mathrm{~g}$ in Figure 2 and Figure 3, respectively. 


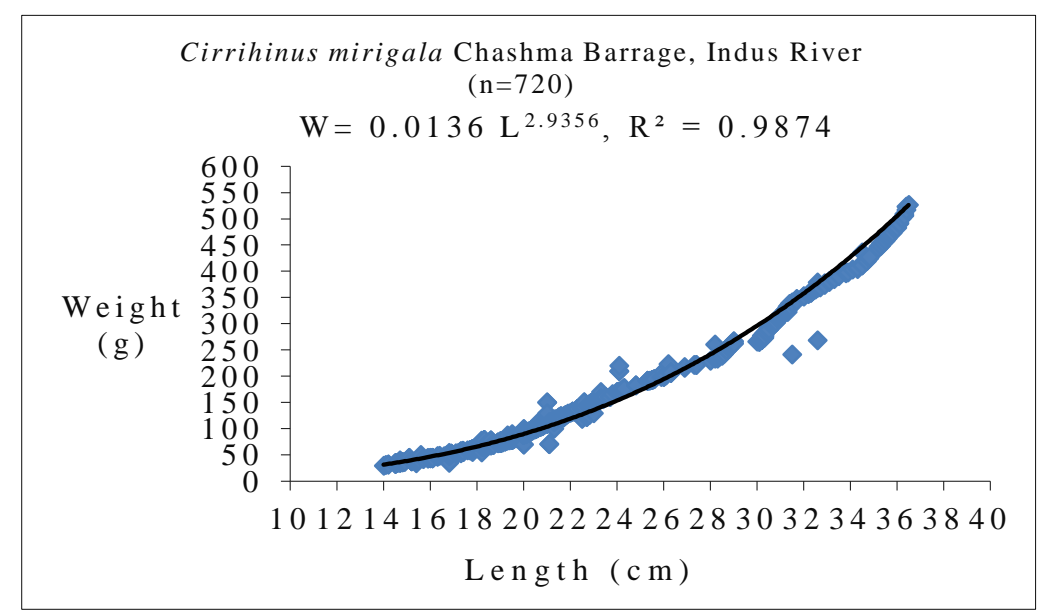

Figure 2. Estimated LWR of Mrigal carp (Eq. 1)

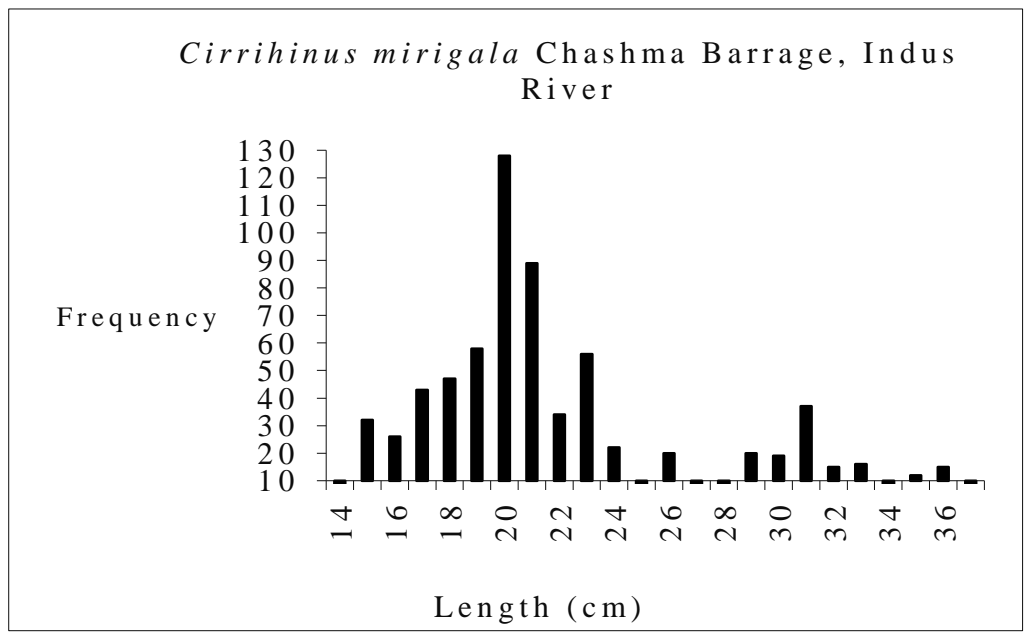

Figure 3. Estimated length frequency distribution of Mrigal carp

\section{Growth parameters}

This study enumerated the VBGF parameters, i.e., Lo and K using the K-scan method in the ELEFAN-I in the length of Mrigal carp. The distribution of the monthly lengthfrequency sizes by Mrigal carp is shown in (Table 1) was arranged at $5 \mathrm{~cm}$ intervals. Estimated values of $\mathrm{L}_{\infty}$ and $\mathrm{K}$ for total annual stock were $38.85 \mathrm{~cm} 0.180$ year $^{-1}$. Alternatively, the score or the goodness index $\left(\mathrm{R}_{\mathrm{n}}\right)$ of the ELEFAN-I routine was estimated as 0.307 (Figure 4). The output result of $\mathrm{t}_{0}=-0.056$ at the length of zero is estimated (Table 2) and a pictorial display of these results is shown in Figure 5. 


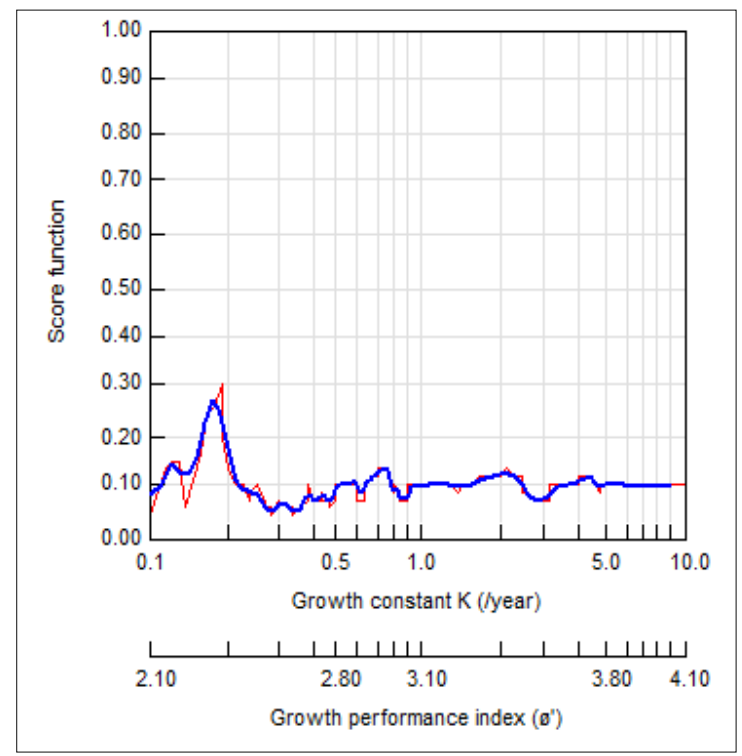

Figure 4. Estimated $\Phi^{\prime}$ index of Mrigal carp (Eq. 2)

Table 2. Estimated population dynamics parameters of Mrigal carp

\begin{tabular}{c|c}
\hline Population parameters & Mrigal carp (Chashma Barrage) \\
\hline $\mathrm{a}$ & 0.014 \\
$\mathrm{~b}$ & 2.936 \\
$\mathrm{R}^{2}$ & 0.987 \\
$\mathrm{~L}_{\infty}$ & $38.85 \mathrm{~cm}$ \\
$\mathrm{~W}_{\infty}$ & $649.501 \mathrm{~g}$ \\
$\mathrm{~K}$ & $0.180 \mathrm{year}^{-1}$ \\
$\mathrm{t}_{0}$ & -0.056 \\
$\mathrm{R}_{\mathrm{n}}$ & 0.307 \\
$\mathrm{Z}$ & 1.170 year $^{-1}$ \\
$\mathrm{~T}$ & $23^{\circ} \mathrm{C}$ \\
$\mathrm{M}$ & $0.493 \mathrm{year}^{-1}$ \\
$\mathrm{~F}$ & 0.677 year $^{-1}$ \\
$\mathrm{E}$ & 0.579 year \\
$\mathrm{U}$ & 0.699 year \\
$\Phi^{\prime}$ & 2.434 year \\
$\Phi$ & 1.13 year \\
$\mathrm{F}_{\max }$ & 0.600 year-1 \\
$\mathrm{F}_{0.1}$ & 0.500 year \\
$\mathrm{R}$ & $14-37 \mathrm{~cm}^{-1}$ \\
$\mathrm{n}$ & 720 \\
\hline
\end{tabular}

\section{Mortality parameters}

Instantaneous $\mathrm{Z}=1.170$ year $^{-1}$ for the total annual stock of Mrigal carp in Chashma Barrage on Indus River at $95 \%$ confidence interval $\left(\mathrm{CI}_{95 \%}\right) 0.770-1.460\left(\mathrm{R}^{2}=0.831\right)$ was calculated from the input values of VBGF parameters $\mathrm{L}_{\infty}$ and $\mathrm{K}$ in the LCCC model in Figure 6 described by Pauly (1983). At the $\mathrm{T}=23^{\circ} \mathrm{C}$ of Chashma Barrage, $\mathrm{M}=0.493$ year $^{-1}$ for the annual production is estimated by Pauly (1980). For this stock, $\mathrm{F}=0.677$ year $^{-1}$ is estimated from the subtraction of $\mathrm{Z}$ from M. E $\left(0.579\right.$ year $\left.^{-1}\right)$ was also attained from division $\mathrm{F}$ by $\mathrm{Z}$ for $\mathrm{Y}$ (Table 2). 


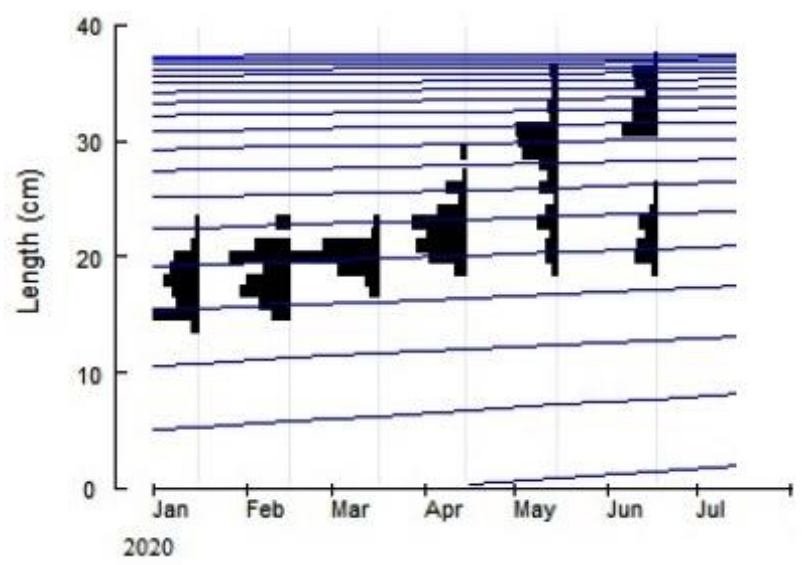

Figure 5. Estimated oscillating growth curves in different months for Mrigal carp (Eq. 3)

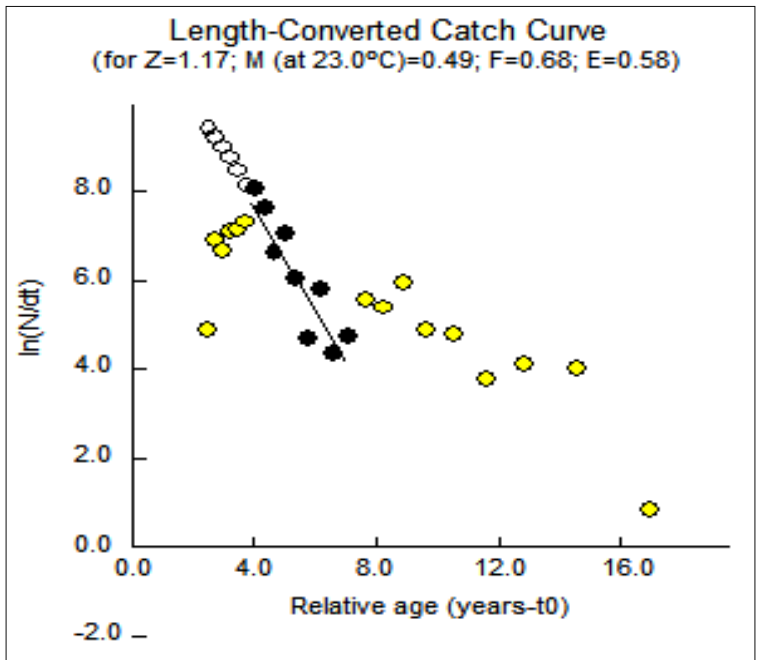

Figure 6. Coefficient of the $Z=1.170$ year $^{-1}$ of Mrigal carp by LCCC (Eq. 4)

\section{VPA}

The parameters of VBGF, i.e., $\mathrm{L}_{\infty}=38.85 \mathrm{~cm}$ and $\mathrm{K}=0,180$ year ${ }^{-1}$, parameters of mortality $\mathrm{M}=0.493$ year $^{-1}, \mathrm{~F}=0.677$ year $^{-1}$ and relationship of correlation parameters $a=0.014$ and $b=2.936$ were developed for VPA for Mrigal carp at Chashma Barrage on the Indus River. FiSAT-II was used for graphical analysis of LSVPA production (Figure 7). The highest fishing limit at the $\mathrm{Y}$ was found in the 30 to $34 \mathrm{~cm}$ range.

\section{Analysis of the $\mathrm{Y} / \mathrm{R}$}

The Beverton-Holt model for Mrigal carp was analyzed by the selection of knife-edge in the FiSAT-II program for the yield per recruit isopleth diagram (Figure 8). When $\mathrm{t}_{\mathrm{c}}$ at 1 the $F_{\max }$ and $F_{0.1}$ for the total annual catches are estimated 0.600 and 0.500 years respectively. Because in the first catch the current age was approximately 1 year and output was current fishing mortality $\left(\mathrm{F}_{\text {current }}\right)=0.677$ year $^{-1}$. TRPs, $\mathrm{F}_{\max }$ and $\mathrm{F}_{0.1}$ are below the limit fishing range $F_{\text {current }} 0.677$ yaer $^{-1}$ stock indicates high volatility for the Mrigal carp fishery in the Chashma Barrage. 


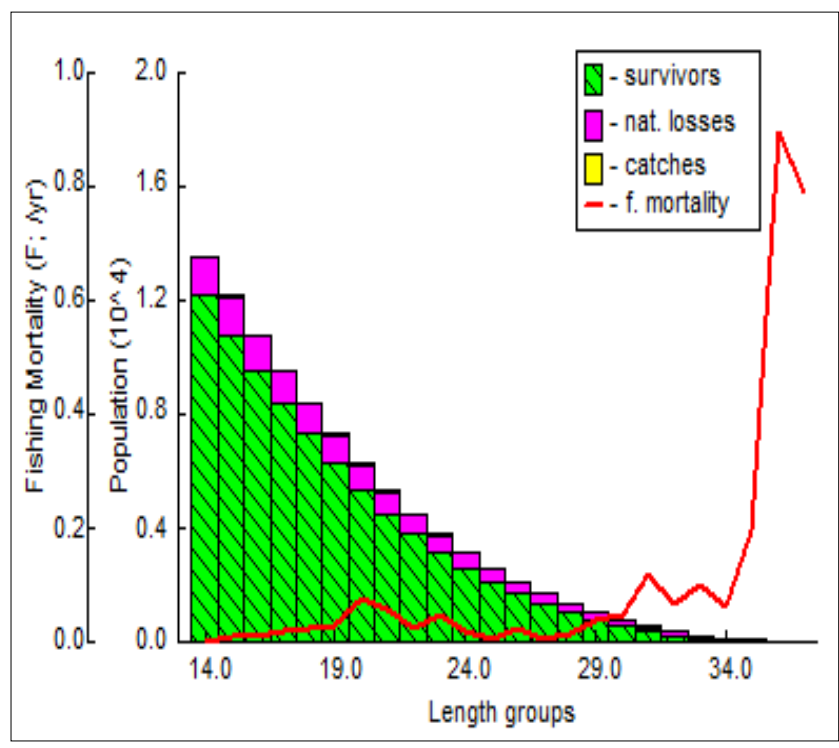

Figure 7. LSVPA for mrigal carp (Eq. 1 and Eq. 2)

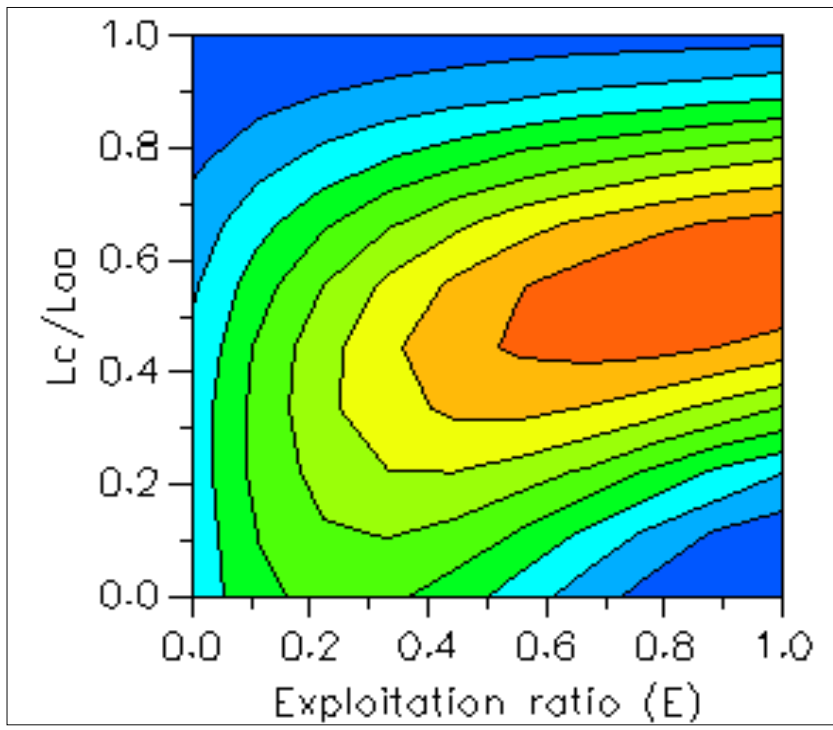

Figure 8. Isopleths yield per recruit contour map for Mrigal carp (Eq. 7)

\section{BRPS}

The $\mathrm{F}_{\text {current }}=0.677$ year $^{-1}$ was rigorously higher compared to estimated value of BRP $\mathrm{F}_{\mathrm{opt}}=0.493$ year $^{-1}$. This is assumed by the method of Gulland (1971b) $\mathrm{F}_{\mathrm{opt}}=\mathrm{M}$ that the stock of this species is overexploitaed severely in Chashma Barrage.

\section{GPI}

The GPI $\Phi^{\prime}=2.434$ and $\Phi=1.130$ years for the total annual stock of Mrigal carp were taken as a result of the input values of the $\mathrm{L}_{\infty}$ and $\mathrm{K}$ of VBGF parameters and asymptotic weight $\left(\mathrm{W}_{\infty}\right)$, respectively. 


\section{MSY}

The $\mathrm{P}=159422 \mathrm{~g}, \mathrm{~B}=157538 \mathrm{~g}$, and $\mathrm{MSY}=92160 \mathrm{~g}$ from Chashma Barrage were estimated for Mrigal carp. The U was estimated at 0.699 . It was revealed from the above results that the stock of Mrigal carp species in Chashma Barrage is highly overfished because the current MSY $=92160 \mathrm{~g}$ was lower than the $\mathrm{P}=159422 \mathrm{~g}$. According to TRP, estimated MSY values $92160 \mathrm{~g}$ for Mrigal carp fishery stock in the Chashma Barrage of Pakistan is far away from the harvested annual stock values of $\mathrm{P}=159422 \mathrm{~g}$ in 2020 , pinpointing this scientifically research in an overexploitation state.

\section{Discussion}

For the effective management and conservation of the natural fish population, the information on stock assessment and evaluation is very important for the development of any stock species. The current study estimates the growth, mortality, exploitation, and MSY parameters in the natural population of Mrigal carp estimated from Chashma Barrage on the Indus River network system. The main objective of the fish population dynamics is to estimate the level of development of fishery resources and essentially recognize the planning, conservation, and management of this commercially and economically important warm-water teleost riverine fishery. In fish population dynamics various tools have been used to evaluate exploitation and stock level. This FiSAT-II software is often and widely used for estimating fish population parameters and requires only LFD (Al-Barwani et al., 2007; Tah et al., 2010). On the biological basis of fisheries management, LWR are useful in determining the weight of individual fish in length or TW based on the LFD. This mathematical relationship between length and weight is an important aspect of biology in calculations. This relationship is used to gain information about the status of fish growth and determine whether somatic development is isometric or allometric (Le Cren, 1951; Ricker, 1975).

For the fish population dynamics, the allometric or isometric growth of fish is an important feature. The $a$ and $b$ parameters of LWR are estimated by the least square regression method. The calculation values of $a$ and $b$ can vary between the individual or grouped data (Ricker, 1975). The estimated LWRs parameters of Mrigal carp freshwater cyprinid fish species from Chashma Barrage of the River Indus basin are coordinated with the previously published values of LWR (Table 3). The growth coefficient factor $\mathrm{b}$ for Mrigal carp is 2.936 in the Chashma Barrage on the River Indus is showing negative allometric growth. The value of $\mathrm{b}$ provides information about the type of fish growth. $\mathrm{R}^{2}$ value indicated the fitness of the regression equation with the highest value 0.987 highly statistically significant in the ecosystem of Chashma Barrage (Figure 2). The estimates value of $\mathrm{b}$ regression coefficient for Mrigal carp was determined from Ahmed and Saha (1996) in Kaptai Lake (1988-1991) Bangladesh 2.657 and $\mathrm{R}^{2}=0.953$ showed negative allometric growth (Table 3). Ahmed et al. (2004) also reported with estimated value of regression $b=2.921, b=2.940$ from Kaptai Lake (1993-95 and 1996-98) Bangladesh close to the calculated values $(b=2.936)$ from the current investigation, respectively. The value of regression coefficient for Mrigal carp $b=2.753$ from Thirumoorthy Reservoir (1993-95), Tamil Nadu, India by Selvaraj et al. (2000) was in comparison with present work from the Chashma Barrage reservoir in Pakistan (Table 3). From the FishBase data (Froese and Pauly, 2019) reported LWR values of Mrigal carp by Sani et al. (2010), Das et al. (2015) and Mayanak et al. (2017) from Gomti River 2007-2009, India, Peninsular Rivers 2009-2012, India and Yamuna River 2011-12, India, respectively, and the values 
of regression coefficients $b=3.520, b=3.355$ and $b=3.104$ showing positive allometric growth, accordingly. From the above estimations, we can assume that the growth of Mrigal carp appears slower in this study.

Table 3. Comparison of estimated LWR parameters of present study with others

\begin{tabular}{|c|c|c|c|c|c|c|c|c|c|}
\hline \multirow{2}{*}{ Reference } & \multirow{2}{*}{ Sex } & \multirow{2}{*}{$\mathbf{n}$} & \multicolumn{3}{|c|}{ Length (cm) } & \multirow{2}{*}{$A$} & \multirow{2}{*}{$\boldsymbol{B}$} & \multirow{2}{*}{$R^{2}$} & \multirow{2}{*}{ Location } \\
\hline & & & Type & Min & Max & & & & \\
\hline Ahmed and Saha (1996) & $\mathrm{C}$ & 253 & $\mathrm{TL}$ & 20.5 & 76 & 0.045 & 2.657 & 0.953 & $\begin{array}{c}\text { Kaptai Lake 1988-91, } \\
\text { Bangladesh }\end{array}$ \\
\hline \multirow[t]{4}{*}{$\begin{array}{l}\text { Ahmed et al. } \\
\text { (2004) }\end{array}$} & $\mathrm{C}$ & 1707 & TL & 17 & 71 & 0.014 & 2.921 & 0.99 & $\begin{array}{c}\text { Kaptai Lake 1993-95, } \\
\text { Bangladesh }\end{array}$ \\
\hline & $\mathrm{C}$ & 905 & TL & 16 & 70 & 0.007 & 3.101 & 0.99 & $\begin{array}{c}\text { Kaptai Lake 1995-96, } \\
\text { Bangladesh }\end{array}$ \\
\hline & $\mathrm{C}$ & 1358 & $\mathrm{TL}$ & 17 & 71 & 0.013 & 2.94 & 0.99 & $\begin{array}{c}\text { Kaptai Lake 1996-98, } \\
\text { Bangladesh }\end{array}$ \\
\hline & $\mathrm{C}$ & 687 & TL & 16 & 72 & 0.011 & 3.001 & 0.99 & $\begin{array}{c}\text { Kaptai Lake 1998-99, } \\
\text { Bangladesh }\end{array}$ \\
\hline Sani et al. $(2010)^{1}$ & $\mathrm{C}$ & 22 & TL & 18 & 31.6 & 0.001 & 3.520 & 0.970 & $\begin{array}{c}\text { Gomti River } \\
\text { 2007-2009, India }\end{array}$ \\
\hline $\begin{array}{l}\text { Rani Palaniswamy et al. } \\
2011 \text { (She used length- }\end{array}$ & & & & & & & & & Thirumoorthy \\
\hline $\begin{array}{l}\text { weight parameters } \\
\text { reported by Selvaraj et } \\
\text { al. } 2000 \text { Thirumoorthy } \\
\text { Reservoir) }\end{array}$ & $\mathrm{C}$ & 3461 & $\mathrm{TL}$ & 42.5 & 59.6 & 0.023 & 2.753 & 0.90 & $\begin{array}{l}\text { Reservoir 1993-95, } \\
\text { Tamil Nadu, India }\end{array}$ \\
\hline Das et al. $(2015)^{1}$ & $\mathrm{C}$ & 265 & TL & 17 & 87 & 0.011 & 3.355 & 0.970 & $\begin{array}{l}\text { Peninsular Rivers } \\
\text { 2009-2012, India }\end{array}$ \\
\hline Mayank et al. $(2017)^{1}$ & $\mathrm{C}$ & 335 & TL & 16.8 & 94.3 & 0.007 & 3.104 & 0.982 & $\begin{array}{l}\text { Yamuna River } \\
\text { 2011-12, India }\end{array}$ \\
\hline $\begin{array}{l}\text { Mohsin et al. (2020) } \\
\text { Present study }\end{array}$ & $\mathrm{C}$ & 720 & $\mathrm{TL}$ & 14 & 37 & 0.014 & 2.936 & 0.987 & $\begin{array}{l}\text { Chashma Barrage } \\
\text { 2020, River Indus, } \\
\text { Pakistan }\end{array}$ \\
\hline
\end{tabular}

1: No references on LWR in FishBase; Min: minimum; Max: maximum; $\mathrm{R}^{2}$ : coefficient of determination;

C: combined sexes; M: male; F: female

This difference may be attributed to various combinations of environmental factors, local zone, cyclical effects, drought, pollution, overfishing or illegal poaching, maturity, and so on (Le Cren, 1951; Beverton and Holt, 1957; Khan et al., 2008).

The estimated regression coefficient value for Mrigal carp from Chashma Barrage $\mathrm{b}=2.936$ was within the agreement in the present study, as reported by the range of exponent regression factor b typically lies between 2.5 to 3.5 (Beverton and Holt, 1957; Pauly and Gayanilo, 1997). According to Martin (1949) and Quinn and Deriso (1999) for the ideal fish, the value of b usually remains at 3.0. However, Beverton and Holt (1957) suggested that a value of 3.0 is rare in adult fish. The current study showed the difference of Mrigal carp stock from the value of ideal growth. This is because the rate of increase in body length is not commensurate with the rate of increase in body weight when the exponent factor is compared to $b=2.936$. In general, fish do not maintain their overall shape or body-line during their lifetime (Le Cren, 1951). If the b value is less than three the fishes will be light in growth, but the value of $b$ is more than three the fishes might be heavy, wherein if the $b$ value is equal to 3 the isometric growth will be formed for the fishes (Quinn and Deriso, 1999). Isometric growth represents a certain body shape of fish 
that would remain proportional throughout life in general (Pauly and Gayanilo, 1997). Growth is an isometric when b expresses the value 3, allometric growth indicates \# 3, growth refers $<3$ the allometric growth will be formed and growth denotes $>3$ the allometric growth of fishes will be called. The LWR results obtained in this study can be considered sound when the fish population is subject to fishing regulations, recovery programs, or other fisheries management activities in related rivers. Consequently, our study will provide the first basic and baseline information on LWR for the indigenous Mrigal carp fish from the Chashma Barrage on the Indus River to the fishery biologists and conservationists. This is useful for the management to apply and enforce sufficient rules for sustainable fisheries stock in the area.

For determining the population dynamics parameters using LFD is very important. The distribution of the LFD is a basic and major representative of the growth method of many aspects of fisheries (Tah et al., 2010). The distribution of LFD of a fish is important in determining the position of the fish population size structure in nature (Jisr et al., 2018). The LFD distribution for Pakistan's freshwater fish resources are limited and the current contribution is aimed at high demand in the country. The LFD provides information about the specific size of the fish within a given population and their relative frequency. The model length range is collected from the analysis of the LFD for information about age group in a population (Jisr et al., 2018). The scales and otoliths are the hardest part of the fish which determines the age and growth of fish in warmer areas for the stock assessment rather than in tropical regions of the world. However, the LFD is a good option in tropical countries for the age of fish determination and stock estimation and assessment (Sparre and Venema, 1992).

The total lengths of fish were grouped into $5 \mathrm{~cm}$ interval size in different classes and the percentage frequency was used for the LFD (Table 1). The LFD was investigated and suggested that Mrigal carp was more than one size group due to multi-model size distribution and perceived several size groups in the fish population in Chashma Barrage (Figure 5). The total length 14 to $37 \mathrm{~cm}$ of LFD showed poly-modal distribution and recorded best modal size class of $21-25 \mathrm{~cm}$ of the highest frequency accounted for $43.889 \%$ of the total specimen examined followed by the $16-20 \mathrm{~cm} 30.694 \%$ over others (Table 1, Figure 3). The LFD are filled in 11-40 cm depending on the size of the class results and it is necessary to monitor and manage these size groups. The declining population of these size groups could adversely affect the population of Mrigal carp in the Chashma Barrage. This is justified in this study that these size groups $21-25 \mathrm{~cm}$ $(43.889 \%)$ and $16-20 \mathrm{~cm}(30.694 \%)$ are exploited and overfished. It is observed that the distribution of the length of the Mrigal carp has management effects for resilience. To determine and establish the true picture of the LFD of the Mrigal carp the use of selection gears in this area must be focused on in the future and further studies. Generally, this study has contributed to the population dynamics parameters and MSY information can be utilized for fishery management.

The growth of the Mrigal carp fishery in Chashma Barrage in Pakistan is characterized by a slow growth rate, due to the VBGF model parameters $\mathrm{L}_{\infty}=38.85 \mathrm{~cm}, \mathrm{~K}=0.180$ year $^{-1}$, and $t_{0}=-0.056$ showed slow growth rate. Growth characteristics are the distinctive signs of good health of the whole population. The growth parameters vary by species or stock to stock in the same species, the growth criteria of a certain species may vary at different rates in different parts of the boundary (Sparre and Venema, 1992). L $\infty$ should be relatively close to the maximum length of the study during the fish sampling period (Moreau et al., 1986), current investigation of $\mathrm{L}_{\infty}=38.85 \mathrm{~cm}$ is within the acceptable 
range of $37.00 \mathrm{~cm}$. The $t_{0}$ can be used as a position parameter and should be less than zero when determining the starting point of the curve where at the zero-age the positive length of fish may occur. The value of $t_{0}$ is an indicator of growth in the organism, the negative value of $t_{0}$ means a higher growth than the expected growth curve, and a positive $t_{0}$ indicates slower growth (King, 1997). $A R_{n}$ can be used for seasonal growth curves because it optimizes LFD and pinpoints $\mathrm{K}$ values for the analysis of growth. This is different than the $\mathrm{R}^{2}$ in FiSAT-II, due to the inability to construct a confidence interval for standard error of estimated $\mathrm{Z}$. The fit index value $\mathrm{R}_{\mathrm{n}}=0.307$ showing more suitable growth for this fish (Figure 4 and Figure 5), between 0 and 1 indicating a good fit for growth but the entire population close 1 shows the most appropriate fit (Gayanilo et al., 2005).

To explain the fish growth, VBGF is the most common and widely used model nowadays (Etim et al., 1999). However, VBGF does not take into account the effects of seasonal variations. The exactness and reliability of $\mathrm{L}_{\infty}$ and $\mathrm{K}$ values are a function of several factors such as the source of biological information. The $\mathrm{L}_{\infty}$ is the maximum theoretical length that an average length species can achieve in the habitat of its environmental characteristics, and $\mathrm{K}$ is the rate of speed where it increases in the direction of the final size (Etim et al., 1999). The higher values of the K are typically connected with lower values of $L_{\infty}$ and vice versa since these parameters are interrelated with each other (Beverton and Holt, 1959). These estimated results were compared by various methods and from diverse data revealed considerable variability in growth between the various populations (Table 4). The estimated growth parameter $\mathrm{L}_{\infty}$ and $\mathrm{K}$ values were the lowest for this fishery from the reported values from the FishBase data (Froese and Pauly, 2019) in Yamuna River, India (Mayank et al., 2017) and other findings in Kaptai Lake Bangladesh by Ahmed et al. (2004) and Thirumoorthy Reservoir India by Rani Palaniswamy et al. (2011). This clearly showed quite a lower convincing growth rate in the population of Mrigal carp in Chashma Barrage under seasonal growth oscillation for the same species from the various geographic localities (Table 4). This attribution may be due to various environmental factors such as behavior, distribution, and density, etc., or possibly seasonal growth oscillations of Mrigal carp in Chashma Barrage on the Indus River can be linked to water temperature $24-31^{\circ} \mathrm{C}$ for slow growth as the tropical country. The slow growth rate for this fishery in Pakistan may be due to high demand to trade-off due to seasonal fishing (Khan et al., 2008) between growth and breeding especially spawning season for this fishery in July in Pakistan (Iqbal and Kausar, 2009).

Table 4. Comparison of estimated growth parameters of Cirrhinus mrigala from Chashma Barrage on the Indus River with the other estimated growth parameters from the different country regions

\begin{tabular}{c|c|c|c|c|c|c}
\hline Reference & $\boldsymbol{L}_{\infty}(\mathbf{c m})$ & $\boldsymbol{K}\left(\mathbf{y e a r}^{-1}\right)$ & $\boldsymbol{t}_{\boldsymbol{0}}$ & $\boldsymbol{\Phi}^{\prime}\left(\mathbf{L}_{\infty}\right)$ & $\boldsymbol{R}_{\boldsymbol{n}}$ & Location \\
\hline & 73 & 0.56 & - & 3.47 & 0.141 & Kaptai Lake 1993-95, Bangladesh \\
Ahmed et al. & 78.1 & 0.48 & - & 3.47 & 0.14 & Kaptai Lake 1995-96, Bangladesh \\
$(2004)$ & 83 & 0.64 & - & 3.64 & 0.114 & Kaptai Lake 1996-98, Bangladesh \\
& 85.07 & 0.43 & - & 3.48 & 0.137 & Kaptai Lake 1998-99, Bangladesh \\
$\begin{array}{c}\text { Rani Palaniswamy } \\
\text { et al. (2011) }\end{array}$ & 71 & 0.845 & -0.05 & 5.629 & - & $\begin{array}{c}\text { Thirumoorthy Reservoir 1993- } \\
\text { 95, Tamil Nadu, India }\end{array}$ \\
$\begin{array}{c}\text { Mayank et al. (2017) } \\
\text { Mohsin et al. (2020) } \\
\text { Present study }\end{array}$ & 99.8 & 1.339 & 0.65 & 4.13 & - & Yamuna River 2011-12, India \\
Chashma Barrage 2020, River \\
\hline
\end{tabular}


Mortality parameters are important indicators of the decomposition rate of the population, they do not need to assume constant and they may change from time to time with a slight instability of growth parameter in the calculation of mortality (Sparre and Venema, 1992). Z (1.170 year $\left.{ }^{-1}\right)$ and M (0.493 year $\left.{ }^{-1}\right)$ of Mrigal carp was lower than the other reported studies from Kaptai Lake 1993-95, 1995-96, 1996-98 and 1998-99, Bangladesh (Ahmed et al., 2004), Thirumoorthy Reservoir 1993-95, India (Rani Palaniswamy et al., 2011) and Yamuna River 2011-12, India (Mayank et al., 2017) (Table 5). These differences may be due to overfishing or may be due to the temperature or adverse ecological circumstances. Under normal circumstances, estimating $\mathbf{M}$ in an exploited fish stock is generally very difficult (Beverton and Holt, 1957; Etim et al., 1999; Quinn and Deriso, 1999; Gayanilo et al., 2005). The value of $Z$ indicated that this fishery is heavily exploited at Chashma Barrage and largely influenced by the extent of fishing intensity. Similarly, it was found that Mrigal carp showed higher Z than F (0.677 year $\left.{ }^{-1}\right)$ and having small $\mathrm{L}_{\infty}(38.85 \mathrm{~cm})$ in Chashma Barrage on River Indus. According to Lorenzen and Enberg (2002), $\mathrm{L}_{\infty}$ is a linear declining function of population biomass density. The $\mathrm{L}_{\infty}$ for Mrigal carp decreases in the Chashma Barrage because population biomass density requires more maintenance and conservation than unmanaged reservoirs and open rivers. The $\mathrm{L}_{\infty}$ of Mrigal carp in the present study has significantly declined from the reported values mentioned in (Table 4), which calls for further improvement and development in the proportion of biomass density of this species and optimum effort of fishing should be reduced till the minimum harvestable size takes place in Chashma Barrage. Hence increasing the fishing effort will further decrease the minimum harvesting size of Mrigal carp in the Chashma Barrage than the present investigating. The state of $\mathrm{M}$ of a fish is inversely related to $\mathrm{L}_{\infty}$ and $\mathrm{K}$ and directly related to the life span of the fishes (Beverton and Holt, 1959). This study is justifying for Mrigal carp in the Chashma Barrage because $\mathrm{M}$ is lower than $\mathrm{F}$ and having a small $\mathrm{L}_{\infty}$ as compared to other reported studies (Table 5). On the other hand, it was found that higher $\mathrm{K}$ value and small life span as reported from other regions (Table 4). The high $\mathrm{F}$ was observed for commercially important fish Mrigal carp from other reported regions as well as from Pakistan (Table 5). The ratio of $\mathrm{M} / \mathrm{K}$ (2.739) obtained also represented overexploitation because this ratio usually falls within the range of 1.12 to 2.50 for most of the fishes (Beverton and Holt, 1957). So, estimated $M / K$ ratio is greater than the reported range and hence suggesting that our estimated $\mathrm{F}$ is at a dangerous level and should be kept below the exploitation rate 0.5 (Gulland, 1971b). E indicates the premise state of exploitation of a stock is being exploited. An estimated E ( 0.579 years) for the total yield was higher than the Gulland (1971b) method, which suggested that E should be lower than 0.5 and greater than 0.5 is considered overexploited.

The $\Phi^{\prime}$ is conducive in both movement $\left(\mathrm{K}\right.$ and $\left.\mathrm{L}_{\infty}\right)$ between species and growth. To compare the growth, we used $\Phi^{\prime}$ of the overall growth of Pauly and Munro (1984). Comparison of the growth rate is a multivariate problem that must take into account both considerations of $\mathrm{K}$ and $\mathrm{L}_{\infty}$ (Etim et al., 1999). Since, $\Phi$ ' meets with these criteria because it is easy to calculate and express the slightest variance when compared with the other alternative indices. $\Phi^{\prime}$ helps to explain the characteristics of the different ecosystems of the stock or housing of the different populations of the environment (Baijot and Moreau, 1997). $\Phi^{\prime}$ are usually species-specific and gross disparity parameters of $\Phi^{\prime}$ values for distinct populations of the same species or family or related species is an indicator of the lack of reliability in the precision of anticipated growth parameters. In this way, the similarity of $\Phi^{\prime}$ with related species in different regions emphasizes the reliability of the 
calculated growth parameters. Computed value of $\Phi^{\prime}=2.434$ (Table 4) compared to their respective performances in the other reported investigations by Ahmed et al. (2004) $\left(\Phi^{\prime}=3.47\right.$ to 3.64), Rani Palaniswamy et al. $(2011)\left(\Phi^{\prime}=5.629\right)$ and Mayank et al. (2017) $\left(\Phi^{\prime}=4.130\right)$ is justified slow growth rate in the present investigation. The reported average range value of $\Phi^{\prime}$ for important fish species lies between the range within 2.650 to 3.320 (Baijot and Moreau, 1997) justifying the estimated growth rate poor for Mrigal carp value $\Phi^{\prime}=2.434$ lower than the reported range in Chashma Barrage.

Table 5. Comparison of estimated mortality parameters of Cirrhinus mrigala from Chashma Barrage on the Indus River with the other estimated mortality parameters from the different country regions

\begin{tabular}{|c|c|c|c|c|c|c|}
\hline Reference & $Z$ year $^{-1}$ & $M$ year $^{-1}$ & $F$ year $^{-1}$ & $E$ year & $U$ year & Location \\
\hline \multirow{4}{*}{ Ahmed et al. (2004) } & 1.89 & 0.77 & 1.12 & 0.59 & - & Kaptai Lake 1993-95, Bangladesh \\
\hline & 1.96 & 0.83 & 1.11 & 0.58 & - & Kaptai Lake 1995-96, Bangladesh \\
\hline & 2.29 & 0.9 & 1.30 & 0.57 & - & Kaptai Lake 1996-98, Bangladesh \\
\hline & 2.04 & 0.75 & 1.29 & 0.63 & - & Kaptai Lake 1998-99, Bangladesh \\
\hline $\begin{array}{l}\text { Rani Palaniswamy } \\
\text { et al. (2011) }\end{array}$ & 2.10 & 0.627 & 1.473 & 0.701 & - & $\begin{array}{c}\text { Thirumoorthy Reservoir 1993- } \\
\text { 95,Tamil Nadu, India }\end{array}$ \\
\hline Mayank et al. (2017) & 4.01 & 0.784 & 3.226 & 0.804 & 0.7898 & Yamuna River 2011-12, India \\
\hline $\begin{array}{l}\text { Mohsin et al. (2020) } \\
\text { Present study }\end{array}$ & 1.170 & 0.493 & 0.677 & 0.579 & 0.699 & $\begin{array}{c}\text { Chashma Barrage 2020, River } \\
\text { Indus, Pakistan }\end{array}$ \\
\hline
\end{tabular}

BRPs are usually a combination of various elements such as the stock dynamic, growth, recruitment, and mortality. They can give a basic philosophy about the status of the fish stock due to meaningful and significant character. BRPs in our study were estimated as designed by Patterson (1992) $\mathrm{F}_{\mathrm{opt}}=0.5 \mathrm{M}\left(0.247, \mathrm{~F}_{\mathrm{opt}}\right)$ and $\mathrm{F}_{\text {limit }}=2 / 3 \mathrm{M}$ $\left(0.329, F_{\text {limit }}\right)$, these values were lower than the estimated method of Gulland (1969) $\mathrm{M}=0.493$ year $^{-1} . \mathrm{F}_{0.1}$ in BRP with respect of $\mathrm{F}_{\max }$ is considered a target of biological safety measure. These BRPs $F_{0.1}$ and $F_{\max }$ indicate only excessive growth rather than excessive recruitment. The Isopleths diagram of yield per recruit contour map (Figure 8) showed that when $t_{c}$ was at 1 , the $F_{\max }(0.600 /$ year $)$ and $F_{0.1}(0.500 /$ year $)$ indicating the stock of Mrigal carp fishery in Chashma Barrage on River Indus is overexploited. Because the current age at the first capture was about 1 year, $F_{\text {current }}$ of 0.677 year $^{-1}$ is higher than BRP $\left(\mathrm{F}_{\mathrm{opt}}=0.493\right.$ year $\left.^{-1}\right)$ target benchmark following Gulland $(1971 \mathrm{~b})$ method. Our result of exploitation rate for Mrigal carp $\mathrm{E}=0.579$ year and exploitation ratio $U=0.699$ is also higher according to the method of Gulland $(1971 \mathrm{~b}, 1979)$ who suggests that the estimated exploitation rate higher than 0.5 indicates high fishing pressure and not ideal for the stock of Mrigal carp in Chashma Barrage. It is recommended to reduce the fishing effort because the available information is limited to compare the life history parameters estimated in this study with those from other studies revealed that the stock of Mrigal carp is overexploited from the reported authors. Our life history parameters estimates may raise some concerns about this aspect from the fishery science community.

The MSY study is a fundamental tool in the assessment and evaluation of fish stocks, and the most important role of MSY is to facilitate the understanding of stock exploitation on a large-scale (Hilborn and Walters, 1992; Hoggarth et al., 2006). MSY is often regarded as a BRP through which a permanent sustainable exploitation objective can be 
achieved (Hilborn and Walters, 1992). BRP is defined as the fishery mortality rate or biomass level, which may be the best catch for long-term sustainable exploitation of stocks (Hoggarth et al., 2006). Globally reference points (RPs) indicators (MSY, biomass at MSY, i.e., $\mathrm{B}_{\mathrm{MSY}}$, fishing mortality at MSY, i.e., $\mathrm{F}_{\mathrm{MSY}}$ ) are normally raised in the science of fisheries management for the choice of management objectives and tracking the status of fisheries (Hoggarth et al., 2006). These are also known as Technical Reference Points (TRPs) or BRPs. These RPs were determined in FAO's Code of Conduct for Responsible Fisheries in 1992 and have become part of it nowadays (FAO, 1995). The conventional concept of MSY target, which stands outstanding on production models, commonly is now seen to be a risk-prone strategy, instead of both targets BRPs (TRPs) and limit reference point (LRPs).

MSY was first embedded in 1982 in the United Nations Convention on the Law of the Sea (UNCLOS), where it is defined as "to guide fisheries" specified as a standard target for fisheries exploitation. Later it was defined LRPs and TRPs entirely in terms of the BRPs related to MSY, BMSY, and FMSY in the 1995 UN Fish Stocks Agreement (FAO, 1995). It has also been the single RP used in Pakistan's Marine Fisheries Policy (Fanning et al., 2016). Because Pakistan has not developed any specific RPs in the current fisheries policy so the stock assessment results of Mrigal carp are based on the indicators that are specified by UNCLOS. These RPs are the precautionary approach that suggests targeting sustainable fisheries in the best interest of the national level.

The estimated MSY=92160 g values in terms of RPs for Mrigal carp fishery indicating overexploitation based on TRPs and LRPs from Chashma Barrage in Pakistan. The current MSY=92160 g was lower than the $\mathrm{P}=159422 \mathrm{~g}$ and $\mathrm{B}=157538 \mathrm{~g}$. Thus, the stock of Mrigal carp fishery is identifying precisely in overexploitation state. Due to the intense increase in the fast-growing demand and necessity of local consumption, the living freshwater aquatic resources are being exploited without long-term ecological and economic sustainability of the fisheries in Pakistan. In case of overexploitation, ecological changes can also be natural or anthropogenic, fish stocks sizes and distributions can fluctuate widely even in their natural, unexploited state, due to the variation in environmental factors and effect of other species with which they interact (Hoggarth et al., 2006). The RP can be specified by MSY and catch can be used as a RP to manage a fishery at the point where yield will theoretically be maximized (Hoggarth et al., 2006). MSY is adopted as an objective for example, in Pakistan the long-standing fisheries management approach is built around the concept of MSY and is often taken as a standard target point. MSY can be achieved by decreasing present fishing pressure at the level on the optimal level for exploitation suggested by Gulland $(1971 \mathrm{~b}, 1979)$ and may be used as a guideline for the stock of Mrigal carp in Chashma Barrage. The present investigation clearly showed that this type of exploitation will be harmful to recruitment and stock. So it is recommended that fishing effort should be strictly prohibited in the breeding season (June to July) for Mrigal carp in Chashma Barrage on river Indus, Pakistan for the future benefit for the local fishermen community. At the last, it is necessary to mention that scales can be used to estimate exact age of fish. However, this study does not emply this method rather its estimated fish age by using length-frequency data which may be considered as limitation of this study. 


\section{Conclusion}

This study strived to explore fishery population dynamics and management aspects of Mrigal carp at Chashma Barrage. Collected data showed significant temporal variation and poly-modal distribution. It was found that this fishery resource is experiencing negative allometric growth and slow growth rate. Besides, fishing mortality is quite high as compared to recommended one. Thus, predicted MSY is considerably lower than current catch. Hence, findings of this study signpost that Mrigal carp fishery resource is facing an open access regime at Chashma Barrage which is an obvious consequence of improper management plan or poor implementation of existing policies. Since, various estimated fishery parameters indicate degradation of this fishery resource and overexploitation. Therefore, harvest of Mrigal carp should be lowered according to the estimated TRP. Besides, efforts to conserve and restore this fishery resource should be done. This can be achieved by protecting adult fish by properly implementing ban during the close season. This measure will let fishery stock to breed and enhance their stock. In addition to this, nursery grounds of this fishery resource should be protected from pollution. Moreover, fishery managers should actively participate to manage this fishery resource for future. Furthermore, more in-depth research should be done on various aspects of this species, like length frequency study, age structure study, otolith study and genetic study for the proper management of this economically important fishery.

\section{REFERENCES}

[1] Abell, R., Allan, J. D., Lehner, B. (2007): Unlocking the Potential of Protected Areas for Freshwaters. - Biological Conservation 134(1): 48-63.

[2] Ahmed, K. K., Saha, S. B. (1996): Length-weight Relationship of Major Carps in Kaptai Lake, Bangladesh. - Naga 19(2): 28.

[3] Ahmed, K. K. U., Amin, S. M. N., Haldar, G. C., Mazid, M. A. (2004): Population Dynamics and Stock Assessment of Cirrhinus mrigala (Hamilton) in the Kaptai Reservoir, Bangladesh. - Indian Journal of Fisheries 51(3): 325-333.

[4] Al-Barwani, S. M., Arshad, A., Amin, S. M. N., Japar, S. B., Siraj, S. S., Yap, C. K. (2007): Population Dynamics of the Green Mussel (Perna viridis) from the High Spat-Fall Coastal Water of Malacca, Peninsular Malaysia. - Fisheries Research 84(2): 147-152.

[5] Baijot, E., Moreau, J. (1997): Biology and Demographic Status of the Main Fish Species. - In: Baijot, E., Moreau, J., Bouda, S. (eds.) Hydrological Aspects of Fisheries in Small Reservoirs in the Sahel Region. Wageningen, Netherlands.

[6] Beverton, R. J. H., Holt, S. J. (1957): On the Dynamics of Exploited Fish Population. Springer, Netherlands.

[7] Beverton, R. J. H., Holt, S. J. (1959): A Review of the Life Spans, Natural Mortality, and their relation to Growth and other Physiological Characteristics. - In: Wolstenholme, G. E. W., O'Conner, M. (eds.) The Lifespan of Animals. CIBA Foundation, London.

[8] Das, S. P., Swain, S., Bej, D., Jayasankar, P., Jena, J. K., Das, P. (2015): Length-weight Relationships of Four Cyprinid Species in India. - Journal of Applied Ichthyology 31(3): 583-584.

[9] Etim, L., Lebo, P. E., King, R. P. (1999): The Dynamics of an Exploited Population of a Siluroid Catfish (Schilbe intermidius Reupell 1832) in the Cross River, Nigeria. - Fisheries Research 40(3): 295-307.

[10] Fanning, P., Medley, P., Khan, M. W., Valinassab, T. (2016): Comprehensive Assessment of Pakistan's Marine Fisheries Resources to 2015. - FAO Report, Rome, Italy.

[11] FAO. (1995): Code of Conduct for Responsible Fisheries. - FAO Report, Rome, Italy. 
[12] FAO. (2003): Information of the Fisheries Management in the Islamic Republic of Pakistan. - FAO Report, Rome, Italy.

[13] FAO. (2020): ASFIS List of Species form Statistics Purposes. - FAO Fishery Fact Sheet Collections, Rome, Italy.

[14] Froese, R., Pauly, D. (2019): FishBase. - World Wide Web electronic publication, available at www.fishbase.org, (12/2019).

[15] Gayanilo, F. C., Sparre, P., Pauly, D. (2005): The FAO-ICLARM Stock Assessment Tool (FiSAT) User's Guide. - FAO Computerized Information Series (Fisheries), FAO, Rome, Italy.

[16] Gerritsen, H. D., McGrath, D. (2007): Precision Estimates and Suggested Sample Sizes for Length-frequency Data. - Fishery Bulletin.

[17] Gulland, J. A. (1969): Manual of Methods for Fish Stock Assessment. - Fish Population Analysis, FAO, Rome, Italy.

[18] Gulland, J. A. (1971a): Estimation of Mortality Rates. Annex to Arctic Fisheries Working Group Report. - ICES C. M. Doc. 3 (mimeo).

[19] Gulland, J. A. (1971b): The Fish Resources of the Oceans. - Fishing News, FAO, Rome, Italy.

[20] Gulland, J. A. (1979): Report of the FAO/ UNDP Workshop on the Fishery Resources of the Western Indian Ocean - South equator.

[21] Haddon, M. (2011): Modeling and Quantitative Methods in Fisheries. - Chapman and Hall, London.

[22] Hamilton, F. (1822): An Account of the Fishes found in the River Ganges and its Branches. - Constable and Company, Edinburgh, England.

[23] Hilborn, R., Walters, C. J. (1992): Quantitative Fisheries Stock Assessment. Choice Dynamics and Uncertainty. - Chapman and Hall, New York.

[24] Hoggarth, D. D., Abeyasekera, S., Arthur, R. I., Beddington, J. R., Burn, R. W., Halls, A. S., Kirkwood, G. P., McAllister, M., Medley, P., Mees, C. C., Parkes, G. B., Pilling, G. M., Wakeford, R. C., Welcomme, R. L. (2006): Stock Assessment for Fishery Management. FAO Fisheries Technical Paper, Rome, Italy.

[25] Iqbal, Z., Kausar, S. (2009): Fecundity of Cirrhinus mrigala (Hamilton) reared in Earthen Pond. - Punjab University Journal of Zoology 24(2): 31-39.

[26] Iqbal, Z., Khalid, P., Javed, N. M. (2013): Population Dynamics of Tor macrolepis (Teleostei: Cyprinidae) and other Fishes of Attock Region, Pakistan. - SENRA Academic Publishers, British Columbia.

[27] Jhingran, V. G., Khan, H. A. (1979): Synopsis of Biological Data on the Mrigal Cirrhinus mrigala (Hamilton, 1822). - FAO Fisheries Synopsis, Rome, Italy.

[28] Jisr, N., Younes, G., Sukhn, C., El-Dakdouki, M. H. (2018): Length-weight Relationships and Relative Condition Factor of Fish Inhabiting the Marine Area of the Eastern Mediterranean City, Tripoli-Lebanon. - The Egyptian Journal of Aquatic Research 44(4): 299-305.

[29] Khan, M., Shakir, H. A., Khan, M. N., Abid, M., Mirza, M. R. (2008): Ichthyofaunal Survey of some Freshwater Reservoirs in Punjab. - Journal of Animal and Plant Science 18(4): 151-154.

[30] King, R. P. (1997): Growth Performance of Nigerian Fish Stocks. - Naga 20: 31-35.

[31] Le Cren, E. D. (1951): The Length-weight Relationship and Seasonal Cycle in Gonad Weight and Condition in the Perch (Perca fluviaittlis). - Journal of Animal Ecology 20(2): 201-219.

[32] Lorenzen, K., Enberg, K. (2002): Density-dependent Growth as a Key Mechanism in the Regulation of Fish Populations: Evidence from among-population comparisons. Proceeding of the Royal Society of London B.

[33] Martin, W. R. (1949): The Mechanics of Environmental Control of Body Form in Fishes. - Fisheries Research Lab, University of Toronto Studies in Biological Series 58, Ontario. 
[34] Mayank, P., Rizvi, A. F., Dwivedi, A. C. (2017): Population Dynamics of Cirrhinus mrigala (Hamilton 1822) from the largest Tributary of the Ganga River, India. International Journal of Fauna and Biological Studies 4(4): 42-47.

[35] Menon, A. G. K. (1999): Check List-Fresh Water Fishes of India (Recorded of the Zoological Survey of India). - The Survey, USA.

[36] Mirza, M. R. (1975): Freshwater Fishes and Zoogeography of Pakistan. - Bijdragen tot de Dierknnde 45: 143-180.

[37] Mirza, M. R., Abu-Bakar, K. (1993): Fishes of Chashma Lake, Pakistan. - Biologia 34: 4547.

[38] Moreau, J., Bambino, C., Pauly, D. (1986): A Comparison of Four Indices of Overall Growth performance based on 100 Tilapia populations (Fam. Cichlidae). - The first Asian Fisheries Forum, Selangor, Malaysia.

[39] Nisha, R., Jain, S. (2018): DNA Quantification of Wild and Cultured Cirrhinus mrigala (Hamilton, 1822) collected from different sites of Western Uttar Pradesh, India. International Journal of Zoological Investigations 4(2): 2454-3055.

[40] Palaniswamy, R., Manoharan, S., Geethalakshmi, V. (2011): Assessment of Population Parameters of Indian Major Carps and Common Carp in a Culture based Reservoir. - Indian Journal of Fisheries 58(2): 41-44.

[41] Patterson, K. (1992): Fisheries for Small Pelagic Species: An Empirical Approach to Management Targets. - Reviews in Fish Biology and Fisheries 2: 321-338.

[42] Pauly, D. (1980): On the Interrelationships between Natural Mortality, Growth parameters and mean Environmental Temperature in 175 Fish Stocks. - ICES Journal of Marine Science 39(2): 175-192.

[43] Pauly, D. (1983): Some simple Methods for the Assessment of Tropical Fish Stocks. - FAO Fisheries Technical Paper, Rome, Italy.

[44] Pauly, D., Munro, J. I. (1984): Once more on the Comparison of Growth in Fish and Invertebrates. - FishByte 2: 21-23.

[45] Pauly, D., Gayanilo, Jr. F. C. (1997): A Bee: An Alternative Approach to Estimating the Parameters of a Length-weight Relationship from Length Frequency Samples and their Bulk Weight. - Research Report, NAGA, Manila, Philippines.

[46] Pethiyagoda, R., Meegaskumbura, M., Maduwage, K. (2012): A Synopsis of the South Asian Fishes referred to Puntius (Pisces: Cuprinidae). - Ichthyological Exploration of Freshwaters 23(1): 69.

[47] Phung, S. T. (1988): A Taxonomic Study on the Fishes of Putao Township, Kachin State. - M.Sc. Thesis, Department of Zoology, University of Mandalay, Burma.

[48] Pitcher, T. J., Hart, P. J. B. (1982): Fisheries Ecology. - Chapman and Hall, London.

[49] Quinn, T. I. I., Deriso, R. B. (1999): Quantitative Fish Dynamics. - Oxford University Press, New York.

[50] Rafique, M. (2007): Biosystematics and Distribution of the Freshwater Fishes of Pakistan with special References to the subfamilies Noemacheilinae and Schizothoracinae. - Ph.D. Thesis, Department of Fisheries, UAAR, Rawalpindi, Pakistan.

[51] Rafique, M., Khan, N. U. H. (2012): Distribution and Status of significant Freshwater Fishes of Pakistan. - Records - Zoological Survey of Pakistan 21: 90-95.

[52] Ricker, W. E. (1975): Computation and Interpretation of Biological Statistics of Fish Populations. - Bulletin - Fisheries Research Board of Canada 191: 379-382.

[53] Sani, R., Gupta, B. K., Sarkar, U. K., Pandey, A., Dubey, V. K., Lakra, W. S. (2010): Length-weight relationships of 14 Indian Freshwater Fish species from the Betwa (Yamuna River tributary) and Gomti (Ganga River tributary) rivers. - Journal of Applied Ichthyology 26(3): 456-459.

[54] Selvaraj, C., Murugesan, V. K., Manoharan, S., Karthikeyan, M. (2000): Fish Yield Optimization in Thirumoorthy Reservoir. - Indian Council of Agriculture Research, West Bengal. 
[55] Sheikh, M., Laghari, M. Y., Lashari, P. K., Khooharo, A. R., Narejo, N. T. (2017): Current status of Three Major Carps (Labeo rohita, Cirrhinus mrigala and Catla catla) in the downstream Indus River, Sindh. - Fisheries and Aquaculture Journal 8(2): 1-3.

[56] Sparre, P., Venema, S. C. (1992): Introduction to Tropical Fish Stock Assessment. - FAO Fisheries Technical Paper, Rome, Italy.

[57] Tah, L., Joanny, T. G., N'Douba, V., Kouassi, J. N., Moreau, J. (2010): Preliminary estimates of the Population Parameters of Major Fish Species in Lake Ayamé I (Bia basin; Côte d'Ivoire). - Journal of Applied Ichthyology 26(1): 57-63. 